\title{
Going Green: The Role of the Green Tea Component EGCG in Chemoprevention
}

\section{Laura Schramm*}

Department of Biological Sciences, St. John's University, NY 11439, USA

\begin{abstract}
Tea is one of the most consumed beverages worldwide, and green tea is the least processed from the buds of the Camellia sinensis plant. The most abundant component of green tea is (-)-epigallocatechin-3-gallate (EGCG), which has been the focus of many cell culture, animal and clinical trials, revealing that EGCG possesses antiproliferative, antimutagenic, antioxidant, antibacterial, antiviral and chemopreventive effects. In this review we briefly summarize the mechanism of action(s) of the green tea component EGCG, highlighting recent advances in the epigenetic regulation by EGCG. Additionally, we provide an overview of mouse chemoprevention studies and EGCG chemoprevention clinical trials.
\end{abstract}

Keywords: EGCG; Green tea; Cancer; Chemoprevention

\section{Introduction}

Tea is one of the most consumed beverages worldwide, second only to water, and is produced from the buds of the Camellia sinensis plant. The three major tea types, green, oolong and black teas, all have various processing methods. Green tea is the least processed of the teas and contains less caffeine than both oolong and black teas $[1,2]$. Approximately $78 \%$ of the worldwide tea production is black tea, whereas green tea, mainly consumed in China and Japan, constitutes about $20 \%[1,2]$. The tea plant is considered native to south China and is now cultivated in many other countries. The major teaproducing countries are China, India, Japan, Sri Lanka, Indonesia and Central African countries. The synthesis of catechins and flavonoids by Camellia sinesis leaves occur during the day and are temperature dependent. The major catechins, a group of polyphenols, in green tea include: (-)-Epigallocatechin-3-Gallate (EGCG); (-)-Epigallocatecin (EGC); (-)-Epicatechin (EC); and (-)-Epicatechin Gallate (ECG) (Figure 1), EGCG being the most abundant and best studied (Table 1) [2].

Many studies have demonstrated that green tea, particularly EGCG, possesses antiproliferative [3-6], antimutagenic [7,8], antioxidant [9$11]$, antibacterial $[12]$, antiviral $[13,14]$ and chemopreventive effects [15-23]. Green tea polyphenols, and its major constituent EGCG, have been tested in tissue culture [24-27], animals [3,28-33] and more recently in clinical trials [14,34-38].

In this review we briefly summarize the mechanism of action(s) of the green tea component EGCG, highlighting recent advances in the epigenetic regulation by EGCG. Additionally, we provide an overview of mouse chemoprevention studies and EGCG chemoprevention clinical trials.

\section{Mechanisms of EGCG Action}

Numerous tissue culture studies have identified multiple mechanisms for green tea, most notably for EGCG, in chemoprevention. EGCG has been demonstrated to regulate signal transduction pathways including: JAK/STAT [39]; MAPK [40,41]; PI3K/AKT [42-44]; Wnt [45,46]; Notch [47-49]; NF- $\kappa B$ [50-53] and AP-1[41]. Additionally, green tea has been demonstrated to induce a host of tumor suppressor activities such as: p53 [54-57]; p21 [58,59]; p16 [60] and Rb [61] known to play a role in chemoprevention [62-64]. EGCG has also been shown to play a role in regulating a variety of receptors involved in a host of biological functions. For example, EGCG regulates the activity of the $67-\mathrm{KDa}$ laminin receptor, originally identified as part of the Extracellular Matrix (ECM) functions as part of the translational machinery and as a cell surface receptor [65-69]. Moreover, EGCG can regulate activity of the Androgen Receptor (AR) in prostate cancer [7072] and the Estrogen Receptor (ER) in breast cancer [73,74].

\section{Epigenetic Mechanisms of EGCG}

Nutrients and bioactive food components, including green tea, have been demonstrated to induce epigenetic changes, including alterations in histone modifications and DNA methylation (Figure 2) $[75,76]$. Hypermethylation of promoter regions, CpG islands, is an effective means to silence genes including tumor suppressors, DNA repair enzymes and other genes encoding proteins regulating cell proliferation [28,73,77-79]. Histone acetylation leads to increased gene expression and is regulated by the opposing actions of Histone Acetyltransferases (HATs) and Deacetylases (HDACs), which have been demonstrated to be influenced by dietary compounds [80].

In eukaryotic cells, RNA polymerase II and III promoter activity is inhibited by promoter specific methylation [81], which occurs through the actions of DNA methyl transferases (DNMT1, DNMT3a, DNMT3b) [82]. EGCG has been demonstrated to inhibit the activity of DNMT1 [83]. The activity of RNA polymerase III has been shown to be inhibited by EGCG [84], and more recently RNA polymerase III transcription is modulated by DNMT1 and DNMT3a [85], suggesting that regulation of RNA polymerase III transcription by EGCG may occur via DNA methyltransferases. Also, the methylation of the Gluthathione-S-Transferase Pi (GSTP1) promoter is a molecular marker for prostate cancer and has been demonstrated in over $90 \%$ of invasive cancers of prostate origin and 70\% of Prostatic Intraepithelial

*Corresponding author: Laura Schramm, St. John's University, Department of Biological Sciences, 8000 Utopia Parkway, Queens, NY 11439, USA, Tel: 718990-5558; E-mail: mailto:schramml@stjohns.edu

Received February 23, 2013; Accepted May 10, 2013; Published May 20, 2013

Citation: Schramm L (2013) Going Green: The Role of the Green Tea Component EGCG in Chemoprevention. J Carcinogene Mutagene 4: 142. doi:10.4172/21572518.1000142

Copyright: (c) 2013 Schramm L. This is an open-access article distributed under the terms of the Creative Commons Attribution License, which permits unrestricted use, distribution, and reproduction in any medium, provided the original author and source are credited. 
Citation: Schramm L (2013) Going Green: The Role of the Green Tea Component EGCG in Chemoprevention. J Carcinogene Mutagene 4: 142. doi:10.4172/2157-2518.1000142

A. (-)-Epigallocatechin-3-gallate (EGCG)<smiles>O=C(O[C@H]1Cc2c(O)cc(O)cc2O[C@H]1c1cc(O)c(O)c(O)c1)c1cc(O)c(O)c(O)c1</smiles>

C. (-)- Epicatechin-3-gallate (ECG)<smiles>O=C(O[C@H]1Cc2c(O)cc(O)cc2O[C@H]1c1ccc(O)c(O)c1)c1cc(O)c(O)c(O)c1</smiles>

B. (-)-Epigallocatechin (EGC)<smiles>Oc1cc(O)c2c(c1)O[C@H](c1cc(O)c(O)c(O)c1)[C@H](O)C2</smiles>

D. (-)-Epicatechin (EC)<smiles>Oc1cc(O)c2c(c1)O[C@H](c1cc(O)c(O)c(O)c1)[C@H](O)C2</smiles>

Figure 1: Chemical Structures of Major Green Tea Metabolites.

A. Epigallocatechin-3-Gallate (EGCG),

B. Epigallocatechin (EGC),

C. Epicatechin-3-Gallate (ECG),

D. Epicatechin (EC). Functional groups are denoted in red. Structures created using ChemSpider, a free chemical structure database (http://www.chemspider. $\mathrm{com} /)$.

Neoplasia (PIN) lesions [86]. The loss of GSTP1 expression correlates with decreased prostate cancer survival [87]. Green tea polyphenol treatment inhibited DNMT activity, effectively reactivating GSTP1 expression which may be beneficial in patients with prostate cancer [88]. Recent studies have demonstrated that EGCG induces epigenetic changes modulating hTERT activity, the catalytic subunit of telomerase, which is overexpressed in $90 \%$ of cancers $[89,90]$ through inhibition of DNMT and HAT activity [91]. Furthermore, EGCG has been demonstrated to inhibit promoter methylation of the tumor suppressors' p16 and p15, thereby restoring expression in colon cancer cells [92]. EGCG also inhibits the methylation of the promoter region of the p21/waf1 and Bax genes in prostate cancer cells [93]. Taken together, these data suggest that dietary compounds, such as green tea, can modulate epigenetic regulation of gene expression and have the potential to play a pivotal role in chemoprevention [94].

\section{EGCG as a Chemopreventive in Mouse Models}

"Cancer chemoprevention" was a term first introduced in 1976 by M. Sporn, who defined cancer chemoprevention as the prevention of the occurrence of cancer by the oral administration of one or multiple compounds [95]. During the compilation of this manuscript, a query of EGCG and chemoprevention in the PubMed database indicates there are 154 published studies on EGCG as a chemopreventive agent in mouse cancer models. EGCG exhibited chemopreventive activities in lung, prostate, breast, colon, oral and skin cancers in mouse models.

One study demonstrated that the differential expression of 88 genes in lung tumors compared with normal tissues was reversed by green tea treatment in A/J mice. These authors also identified 17 genes that are altered by tea treatments in both normal lungs and lung adenomas, suggesting that these genes could be used as markers for tea exposure [96]. Also, researchers have demonstrated the prevention of mammary carcinogenesis in C3H/OuJ mice by EGCG [97]. Green tea inhibits development and progression of prostate cancer in transgenic

adenocarcinoma of the mouse prostate [98-100]. Additionally, colon cancer prevention activity by tea polyphenols has been clearly demonstrated in mouse models, but results from studies in rat models have yielded inconsistent results [101]. EGCG has also been successful in inhibiting oral cavity cancer in $\mathrm{C} 3 \mathrm{H} / \mathrm{HeJ}$ mice [102]. Taken together, these data suggest that green tea, especially EGCG, exhibits chemopreventive properties in mouse models.

\section{EGCG as a Chemopreventive in Clinical Trials}

The 2013 cancer statistics reveal that cancer incidences have declined slightly for men, $0.6 \%$, and remained unchanged for women during 2005-2009 [103], suggesting that more efforts are needed to develop chemoprevention therapies. In 1987, EGCG's chemopreventive effect was first reported when the inhibitory effects of EGCG on teleocidininduced tumor promotion in mouse skin was observed [104]. There is an increasing amount of evidence that has been presented, indicating that green tea may be chemopreventive [105].

For example, clinical trials in prostate cancer patients suggest that green tea may play a role as a chemopreventive agent in progression [36]. In Japan, a study including 49,920 males aged 40-69, found that drinking greater than 5 cups of green tea per day showed a reduced risk of developing advanced prostate cancers [106]. Additionally, a double blind randomized trial of 60 patients recently diagnosed with High Grade Prostatic Intraepithelial Neoplasia (HG-PIN), who have a 30\% likelihood of developing one year post HG-PIN diagnosis, was treated with green tea catechins or placebo [107]. The study showed that $30 \%$ of participants receiving the placebo developed HG-PIN after one year compared to the $3 \%$ receiving green tea catechins [107]. Two year

\begin{tabular}{|c|c|}
\hline Green Tea Constituents & $\begin{array}{c}\text { Concentration } \\
\text { (mg/8 fl oz) }\end{array}$ \\
\hline Epigallocatechin-3-Gallate (EGCG) & $25-106$ \\
\hline Epigallocatechin (EGC) & $49-113$ \\
\hline Epicatechin-3-Gallate (ECG) & $4-36$ \\
\hline Epicatechin (EC) & $6-19$ \\
\hline
\end{tabular}

* $\mathrm{fl} \mathrm{oz}=$ fluid ounce, $\mathrm{mg}=$ milligram, $\mathrm{L}=$ liter [2]

Table 1: Major catechin classes identified in green tea.

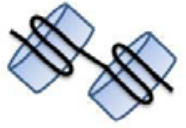
Histone deacetylases (HDACS) leads to decreased gene expression
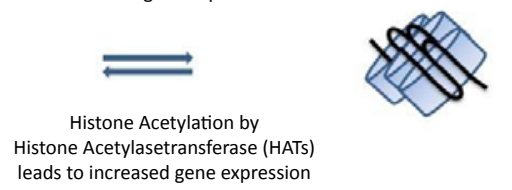
ads to increased gene expression

B.

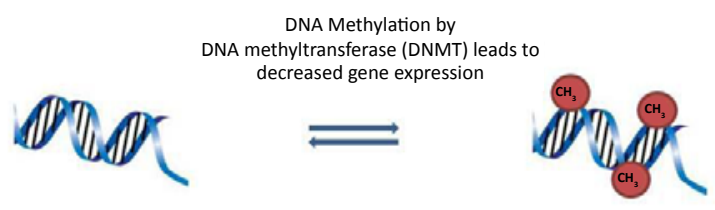

Figure 2: Epigenetic mechanisms regulating gene expression.

A. Acetylation of histones by histone acetyltransferases (HATs) leads to increased gene expression, whereas histone deacetylation by histone deacetyltransferases (HDACs) leads to decreases in gene expression.

B. Methylation of DNA by DNA methyl transferases (DNMTs) leads to gene silencing. 
follow up studies were performed and indicated that green tea catechin prevention was long lasting [108].

Prostate cancer is not the only cancer for which green tea catechins have been demonstrated as a chemopreventive. Recently, studies provide evidence that EGCG has potential to halt carcinogenesis in patients with Head Neck And Squamous Cell Carcinoma (HNSCC) [109]. In a phase II trial, patients with oral premalignant lesions were administered Green Tea Extract (GTE) capsules containing 13.2\% of EGCG three times a day for 12 weeks had statistically significant clinical response rates in comparison to low doses of GTE [109]. Additionally, a colon cancer chemoprevention pilot study demonstrated that administration of $500 \mathrm{mg}$ of GTE tablet containing $52.5 \mathrm{mg}$ of EGCG three times daily for 12 months significantly $(P<0.05)$ inhibited the incidence of secondary metachronous colon adenomas [110].

There have been clinical and epidemiological studies yielding conflicting results for a variety of cancers involving green tea, including: breast [111-113]; colorectal [114,115]; esophageal [116] and lung [117] cancers. In the case of breast cancer, a very large cohort study involving the pooled analysis of two studies with 35,004 Japanese women showed no association between green tea intake and breast cancer risk [112]. These results contradict a previous study examining the association between regular green tea consumption prior to breast cancer incidence and reoccurrence and concluded green tea consumption may be preventive against recurrence of early breast cancer [111]. Colorectal cancer clinical studies have also reported conflicting results. In one study evaluating the association between green tea consumption and colorectal cancer 69,710 Chinese women aged 40 to 70 years were interviewed to ascertain green tea consumption habits and during the six year follow up a dose response protective effect of green tea was noted for women and colorectal cancer [114]. The same protective effect was not as clear cut for male green tea drinkers and colorectal cancer [115]. Mixed results have been reported for esophageal cancers. It appears that the chemopreventive effects of green tea can be counteracted by high temperatures [116]. Also, fewer well controlled clinical studies have looked at chemoprevention of lung cancer by green tea have been undertaken. However, a few well controlled studies indicate that green tea and black tea increased the risk of lung cancer [117].

It is important to note that epidemiological studies data have been used to determine the association between green tea consumption and cancer risk and selected confounding results may be accounted for by differences in lifestyle, diet and genetic variability. Many of the green tea epidemiology studies are done with Asian populations where tea drinking is associated with cigarette smoking and alcohol consumption [118]. Therefore, larger clinical studies controlling for confounders may be warranted to determine if green tea can be used as a general chemopreventive.

Importantly, there were no serious adverse effects documented in any of these green tea clinical trials. The sample sizes for controlled clinical trials are small but nonetheless significant. Even with conflicting epidemiological studies, these small and significant clinical trials further demonstrate the need for larger-scale EGCG chemoprevention studies for a subset of cancers to determine if green tea should be included in the American Recommended Daily Amounts (RDA) as part of a healthy lifestyle.

Green tea has been demonstrated to have a plethora of health benefits including; lowering blood pressure [119], increasing insulin sensitivity [119] and cardiovascular benefits [120]. In addition, EGCG, the major component of green tea, has been implicated in a host of biochemical pathways controlling cell growth and proliferation $[121,122]$. Animal cancer models have demonstrated that EGCG can inhibit tumorigenesis. Although there have been conflicting results for a variety of cancers such as breast [111-113]; colorectal [114,115]; esophageal [116] and lung [117] cancers there is strong evidence from clinical trials for prostate $[31,107,108]$, oral [109] and colon cancer [110] showing promise for the use of green tea for cancer chemoprevention.

Recent 2013 cancer statistics [103] reveal that the incidence of cancer has remained relatively constant, suggesting that larger scale carefully controlled Chemopreventivetive clinical studies using natural products, such as green tea catechins, are warranted.

\section{Acknowledgements}

This work is supported in part by the National Institute of Health AREA grant 1R15CA133842-01A1 (LS). We thank Dr. Stephanie Cabarcas, Gannon University, for critically reading this manuscript.

\section{References}

1. Balentine DA, Wiseman SA, Bouwens LC (1997) The chemistry of tea flavonoids. Crit Rev Food Sci Nutr 37: 693-704.

2. Reto M, Figueira ME, Filipe HM, Almeida CM (2007) Chemical composition of green tea (Camellia sinensis) infusions commercialized in Portugal. Plant Foods Hum Nutr 62: 139-144.

3. Crespy V, Williamson G (2004) A review of the health effects of green tea catechins in in vivo animal models. J Nutr 134: 3431 S-3440S

4. Cooper R, Morre DJ, Morre DM (2005) Medicinal benefits of green tea: part II. review of anticancer properties. J Altern Complement Med 11: 639-652.

5. Cooper R, Morré DJ, Morré DM (2005) Medicinal benefits of green tea: Part I. Review of noncancer health benefits. J Altern Complement Med 11: 521-528.

6. Jochmann N, Baumann G, Stangl V (2008) Green tea and cardiovascular disease: from molecular targets towards human health. Curr Opin Clin Nutr Metab Care 11: 758-765

7. Cheng S, Ding L, Zhen Y, Lin P, Zhu Y, et al. (1991) Progress in studies on the antimutagenicity and anticarcinogenicity of green tea epicatechins. Chin Med Sci J 6: 233-238

8. Gupta S, Saha B, Giri AK (2002) Comparative antimutagenic and anticlastogenic effects of green tea and black tea: a review. Mutat Res 512: 37-65.

9. Lambert JD, Elias RJ (2010) The antioxidant and pro-oxidant activities of green tea polyphenols: a role in cancer prevention. Arch Biochem Biophys 501: 6572.

10. Coentrão Pde A, Teixeira VL, Netto AD (2011) Antioxidant activity of polyphenols from green and toasted mate tea. Nat Prod Commun 6: 651-656.

11. Forester SC, Lambert JD (2011) The role of antioxidant versus pro-oxidant effects of green tea polyphenols in cancer prevention. Mol Nutr Food Res 55 844-854.

12. Cabrera C, Artacho R, Giménez R (2006) Beneficial effects of green tea--a review. J Am Coll Nutr 25: 79-99.

13. Meltzer SM, Monk BJ, Tewari KS (2009) Green tea catechins for treatment of external genital warts. Am J Obstet Gynecol 200: 233.

14. Butler LM, Wu AH (2011) Green and black tea in relation to gynecologic cancers. Mol Nutr Food Res 55: 931-940.

15. Katiyar SK, Agarwal R, Mukhtar H (1992) Green tea in chemoprevention of cancer. Compr Ther 18: 3-8.

16. Gupta S, Ahmad N, Mukhtar H (1999) Prostate cancer chemoprevention by green tea. Semin Urol Oncol 17: 70-76.

17. Mukhtar H, Ahmad N (1999) Green tea in chemoprevention of cancer. Toxicol Sci 52: 111-117.

18. Suganuma M, Okabe S, Sueoka N, Sueoka E, Matsuyama S, et al. (1999) Green tea and cancer chemoprevention. Mutat Res 428: 339-344.

19. Hsu SD, Singh BB, Lewis JB, Borke JL, Dickinson DP, et al. (2002) Chemoprevention of oral cancer by green tea. Gen Dent 50: 140-146. 
Citation: Schramm L (2013) Going Green: The Role of the Green Tea Component EGCG in Chemoprevention. J Carcinogene Mutagene 4: 142. doi:10.4172/2157-2518.1000142

20. Linden KG, Carpenter PM, McLaren CE, Barr RJ, Hite P, et al. (2003) Chemoprevention of nonmelanoma skin cancer: experience with a polypheno from green tea. Recent Results Cancer Res 163: 165-171.

21. Huang J, Plass C, Gerhauser C (2011) Cancer chemoprevention by targeting the epigenome. Curr Drug Targets 12: 1925-1956.

22. Shirakami Y, Shimizu M, Moriwaki H (2012) Cancer chemoprevention with green tea catechins: from bench to bed. Curr Drug Targets 13: 1842-1857.

23. Gerhauser C (2013) Cancer chemoprevention and nutriepigenetics: state of the art and future challenges. Top Curr Chem 329: 73-132.

24. Chen D, Daniel KG, Kuhn DJ, Kazi A, Bhuiyan M, et al. (2004) Green tea and tea polyphenols in cancer prevention. Front Biosci 9: 2618-2631.

25. Yang CS, Sang S, Lambert JD, Hou Z, Ju J, et al. (2006) Possible mechanisms of the cancer-preventive activities of green tea. Mol Nutr Food Res 50: 170-175.

26. Huo C, Wan SB, Lam WH, Li L, Wang Z, et al. (2008) The challenge of developing green tea polyphenols as therapeutic agents. Inflammopharmacology 16: 248252.

27. Henning SM, Wang P, Heber D (2011) Chemopreventive effects of tea in prostate cancer: green tea versus black tea. Mol Nutr Food Res 55: 905-920.

28. Volate SR, Muga SJ, Issa AY, Nitcheva D, Smith T, et al. (2009) Epigenetic modulation of the retinoid $X$ receptor alpha by green tea in the azoxymethaneApc Min/+ mouse model of intestinal cancer. Mol Carcinog 48: 920-933.

29. Adhami VM, Siddiqui IA, Sarfaraz S, Khwaja SI, Hafeez BB, et al. (2009) Effective prostate cancer chemopreventive intervention with green tea polyphenols in the TRAMP model depends on the stage of the disease. Clin Cancer Res 15: 1947-1953.

30. Kaur S, Greaves P, Cooke DN, Edwards R, Steward WP, et al. (2007) Breas cancer prevention by green tea catechins and black tea theaflavins in the C3(1) SV40 T,t antigen transgenic mouse model is accompanied by increased apoptosis and a decrease in oxidative DNA adducts. J Agric Food Chem 55: 3378-3385.

31. Bettuzzi S, Rizzi F, Belloni L (2007) Clinical relevance of the inhibitory effect of green tea catechins (GtCs) on prostate cancer progression in combination with molecular profiling of catechin-resistant tumors: an integrated view. Pol J Vet Sci 10: 57-60.

32. Thangapazham RL, Singh AK, Sharma A, Warren J, Gaddipati JP, et al. (2007) Green tea polyphenols and its constituent epigallocatechin gallate inhibits proliferation of human breast cancer cells in vitro and in vivo. Cancer Lett 245: 232-241.

33. Scaltriti M, Belloni L, Caporali A, Davalli P, Remondini D, et al. (2006) Molecular classification of green tea catechin-sensitive and green tea catechin-resistant prostate cancer in the TRAMP mice model by quantitative real-time PCR gene profiling. Carcinogenesis 27: 1047-1053.

34. Khan N, Mukhtar H (2008) Multitargeted therapy of cancer by green tea polyphenols. Cancer Lett 269: 269-280.

35. Pandey M, Gupta S (2009) Green tea and prostate cancer: from bench to clinic. Front Biosci (Elite Ed) 1: 13-25.

36. Johnson JJ, Bailey HH, Mukhtar H (2010) Green tea polyphenols for prostate cancer chemoprevention: a translational perspective. Phytomedicine 17: 3-13.

37. Kim JW, Amin AR, Shin DM (2010) Chemoprevention of head and neck cancer with green tea polyphenols. Cancer Prev Res (Phila) 3: 900-909.

38. Connors SK, Chornokur G, Kumar NB (2012) New insights into the mechanisms of green tea catechins in the chemoprevention of prostate cancer. Nutr Cancer 64: 4-22.

39. Tedeschi E, Suzuki H, Menegazzi M (2002) Antiinflammatory action of EGCG the main component of green tea, through STAT-1 inhibition. Ann N Y Acad Sci 973: 435-437.

40. Sen T, Dutta A, Chatterjee A (2010) Epigallocatechin-3-gallate (EGCG) downregulates gelatinase-B (MMP-9) by involvement of FAK/ERK/NFkappaB and AP-1 in the human breast cancer cell line MDA-MB-231. Anticancer Drugs 21: $632-644$.

41. Kim HS, Kim MH, Jeong M, Hwang YS, Lim SH, et al. (2004) EGCG blocks tumor promoter-induced MMP-9 expression via suppression of MAPK and AP-1 activation in human gastric AGS cells. Anticancer Res 24: 747-753.
42. Shimizu M, Shirakami Y, Moriwaki H (2008) Targeting receptor tyrosine kinases for chemoprevention by green tea catechin, EGCG. Int J Mol Sci 9: 1034-1049.

43. Masuda M, Wakasaki T, Toh S, Shimizu M, Adachi S (2011) Chemoprevention of Head and Neck Cancer by Green Tea Extract: EGCG-The Role of EGFR Signaling and "Lipid Raft". J Oncol 2011: 540148.

44. Zhang X, Zhang H, Tighiouart M, Lee JE, Shin HJ, et al. (2008) Synergistic inhibition of head and neck tumor growth by green tea (-)-epigallocatechin-3gallate and EGFR tyrosine kinase inhibitor. Int J Cancer 123: 1005-1014.

45. Pahlke G, Ngiewih Y, Kern M, Jakobs S, Marko D, et al. (2006) Impact of quercetin and EGCG on key elements of the Wnt pathway in human colon carcinoma cells. J Agric Food Chem 54: 7075-7082.

46. Kim J, Zhang X, Rieger-Christ KM, Summerhayes IC, Wazer DE, et al. (2006) Suppression of Wnt signaling by the green tea compound (-)-epigallocatechin 3-gallate (EGCG) in invasive breast cancer cells. Requirement of the transcriptional repressor HBP1. J Biol Chem 281: 10865-10875.

47. Hossain MM, Banik NL, Ray SK (2012) Survivin knockdown increased anti-cancer effects of (-)-epigallocatechin-3-gallate in human malignan neuroblastoma SK-N-BE2 and SH-SY5Y cells. Exp Cell Res 318: 1597-1610.

48. Singh BN, Shankar S, Srivastava RK (2011) Green tea catechin epigallocatechin-3-gallate (EGCG): mechanisms, perspectives and clinical applications. Biochem Pharmacol 82: 1807-1821.

49. Liu X, Zhang DY, Zhang W, Zhao X, Yuan C, et al. (2011) The effect of green tea extract and EGCG on the signaling network in squamous cell carcinoma. Nutr Cancer 63: 466-475

50. Yang J, Han Y, Chen C, Sun H, He D, et al. (2013) EGCG attenuates high glucose-induced endothelial cell inflammation by suppression of PKC and NF$\hat{l}^{\circ} \mathrm{B}$ signaling in human umbilical vein endothelial cells. Life Sci 92: 589-597.

51. Cai Y, Yu SS, Chen TT, Gao S, Geng B, et al. (2013) EGCG inhibits CTGF expression via blocking NF-Î० ${ }^{\circ}$ activation in cardiac fibroblast. Phytomedicine 20: $106-113$

52. Vezina, A, Chokor, R, Annabi, B (2012) EGCG targeting efficacy of NFkappaB downstream gene products is dictated by the monocytic/macrophagic differentiation status of promyelocytic leukemia cells. Cancer Immuno Immunother 61: 2321-2331.

53. Syed DN, Afaq F, Kweon MH, Hadi N, Bhatia N, et al. (2007) Green tea polyphenol EGCG suppresses cigarette smoke condensate-induced NFkappaB activation in normal human bronchial epithelial cells. Oncogene 26 : 673-682.

54. Kang SU, Lee BS, Lee SH, Baek SJ, Shin YS, et al. (2012) Expression of NSAID-activated gene-1 by EGCG in head and neck cancer: involvement of ATM-dependent p53 expression. J Nutr Biochem.

55. Thakur VS, Ruhul Amin AR, Paul RK, Gupta K, Hastak K, et al. (2010) p53 Dependent p21-mediated growth arrest pre-empts and protects HCT116 cells from PUMA-mediated apoptosis induced by EGCG. Cancer Lett 296: 225-32.

56. Huang CH, Tsai SJ, Wang YJ, Pan MH, Kao JY, et al. (2009) EGCG inhibits protein synthesis, lipogenesis, and cell cycle progression through activation of AMPK in p53 positive and negative human hepatoma cells. Mol Nutr Food Res 53: $1156-1165$

57. Amin AR, Thakur VS, Paul RK, Feng GS, Qu CK, et al. (2007) SHP-2 tyrosine phosphatase inhibits p73-dependent apoptosis and expression of a subset of p53 target genes induced by EGCG. Proc Natl Acad Sci USA 104: 5419-5424.

58. Bhatia N, Agarwal C, Agarwal R (2001) Differential responses of skin cancerchemopreventive agents silibinin, quercetin, and epigallocatechin 3-gallate on mitogenic signaling and cell cycle regulators in human epidermoid carcinoma A431 cells. Nutr Cancer 39: 292-299.

59. Liberto M, Cobrinik D (2000) Growth factor-dependent induction of p21(CIP1) by the green tea polyphenol, epigallocatechin gallate. Cancer Lett 154: 151 161.

60. Nandakumar V, Vaid M, Katiyar SK (2011) (-)-Epigallocatechin-3-gallate reactivates silenced tumor suppressor genes, Cip1/p21 and p16INK4a, by reducing DNA methylation and increasing histones acetylation in human skin cancer cells. Carcinogenesis 32: 537-544.

61. Ahmad N, Adhami VM, Gupta S, Cheng P, Mukhtar H (2002) Role of the retinoblastoma $(\mathrm{pRb})-\mathrm{E} 2 \mathrm{~F} / \mathrm{DP}$ pathway in cancer chemopreventive effects of green tea polyphenol epigallocatechin-3-gallate. Arch Biochem Biophys 398: 125-131. 
Citation: Schramm L (2013) Going Green: The Role of the Green Tea Component EGCG in Chemoprevention. J Carcinogene Mutagene 4: 142. doi:10.4172/2157-2518.1000142

Page 5 of 6

62. Erker L, Schubert R, Yakushiji H, Barlow C, Larson D, et al. (2005) Cancer chemoprevention by the antioxidant tempol acts partially via the p53 tumor suppressor. Hum Mol Genet 14: 1699-1708.

63. Singh J, Reddy BS (1995) Molecular markers in chemoprevention of colon cancer. Inhibition of expression of ras-p21 and p53 by sulindac during azoxymethane-induced colon carcinogenesis. Ann N Y Acad Sci 768: 205-209.

64. Papadimitrakopoulou VA, Izzo J, Mao L, Keck J, Hamilton D, et al. (2001) Cyclin D1 and p16 alterations in advanced premalignant lesions of the upper aerodigestive tract: role in response to chemoprevention and cancer development. Clin Cancer Res 7: 3127-3134

65. Tsukamoto S, Yamashita S, Kim YH, Kumazoe M, Huang Y, et al. (2012) Oxygen partial pressure modulates $67-\mathrm{kDa}$ laminin receptor expression, leading to altered activity of the green tea polyphenol, EGCG. FEBS Lett 586: 3441-3447.

66. Shukla R, Chanda N, Zambre A, Upendran A, Katti K, et al. (2012) Laminin receptor specific therapeutic gold nanoparticles (198AuNP-EGCg) show efficacy in treating prostate cancer. Proc Natl Acad Sci U S A 109: 1242612431.

67. Fujimura Y, Sumida M, Sugihara K, Tsukamoto S, Yamada K, et al. (2012) Green tea polyphenol EGCG sensing motif on the $67-\mathrm{kDa}$ laminin receptor. PLoS One 7: e37942.

68. Tachibana $H$ (2008) Green tea polyphenol EGCG signaling pathway through the 67-kDa laminin receptor. Nihon Yakurigaku Zasshi 132: 145-149.

69. Fujimura Y, Umeda D, Yano S, Maeda-Yamamoto M, Yamada K, et al. (2007) The $67 \mathrm{kDa}$ laminin receptor as a primary determinant of anti-allergic effects of O-methylated EGCG. Biochem Biophys Res Commun 364: 79-85.

70. Lee YH, Kwak J, Choi HK, Choi KC, Kim S, et al. (2012) EGCG suppresses prostate cancer cell growth modulating acetylation of androgen receptor by anti-histone acetyltransferase activity. Int J Mol Med 30: 69-74.

71. Siddiqui IA, Asim M, Hafeez BB, Adhami VM, Tarapore RS, et al. (2011) Green tea polyphenol EGCG blunts androgen receptor function in prostate cancer. FASEB J 25: 1198-1207.

72. Ren F, Zhang S, Mitchell SH, Butler R, Young CY (2000) Tea polyphenols down-regulate the expression of the androgen receptor in LNCaP prostate cancer cells. Oncogene 19: 1924-1932.

73. Li Y, Yuan YY, Meeran SM, Tollefsbol TO (2010) Synergistic epigenetic reactivation of estrogen receptor-Ît (ERÎ \pm ) by combined green tea polyphenol and histone deacetylase inhibitor in ERÎt-negative breast cancer cells. Mol Cancer 9: 274

74. Belguise K, Guo S, Sonenshein GE (2007) Activation of FOXO3a by the green tea polyphenol epigallocatechin-3-gallate induces estrogen receptor alpha expression reversing invasive phenotype of breast cancer cells. Cancer Res 67: $5763-5770$.

75. Choi SW, Friso S (2010) Epigenetics: A New Bridge between Nutrition and Health. Adv Nutr 1: 8-16.

76. Sokolosky ML, Wargovich MJ (2012) Homeostatic imbalance and colon cancer: the dynamic epigenetic interplay of inflammation, environmental toxins, and chemopreventive plant compounds. Front Oncol 2: 57.

77. Burzynski SR (2005) Aging: gene silencing or gene activation? Med Hypotheses 64: 201-208.

78. Esteller M (2002) CpG island hypermethylation and tumor suppressor genes: a booming present, a brighter future. Oncogene 21: 5427-5440.

79. Esteller M, Herman JG (2002) Cancer as an epigenetic disease: DNA methylation and chromatin alterations in human tumours. J Pathol 196: 1-7.

80. Pham TX, Lee J (2012) Dietary regulation of histone acetylases and deacetylases for the prevention of metabolic diseases. Nutrients 4: 1868-1886.

81. Muiznieks I, Doerfler W (1994) The topology of the promoter of RNA polymerase II- and III-transcribed genes is modified by the methylation of 5'CG-3' dinucleotides. Nucleic Acids Res 22: 2568-2575.

82. Jin B, Robertson KD (2013) DNA methyltransferases, DNA damage repair, and cancer. Adv Exp Med Biol 754: 3-29.

83. Fang MZ, Wang Y, Ai N, Hou Z, Sun Y, et al. (2003) Tea polyphenol (-)-epigallocatechin-3-gallate inhibits DNA methyltransferase and reactivates methylation-silenced genes in cancer cell lines. Cancer Res 63: 7563-7570.
84. Jacob J, Cabarcas S, Veras I, Zaveri N, Schramm L (2007) The green tea component EGCG inhibits RNA polymerase III transcription. Biochem Biophys Res Commun 360: 778-783.

85. Selvakumar T, Gjidoda A, Hovde SL, Henry RW (2012) Regulation of human RNA polymerase III transcription by DNMT1 and DNMT3a DNA methyltransferases. J Biol Chem 287: 7039-7050.

86. Nakayama M, Gonzalgo ML, Yegnasubramanian S, Lin X, De Marzo AM, et al. (2004) GSTP1 CpG island hypermethylation as a molecular biomarker for prostate cancer. J Cell Biochem 91: 540-552.

87. Re A, Aiello A, Nanni S, Grasselli A, Benvenuti V, et al. (2011) Silencing of GSTP1, a prostate cancer prognostic gene, by the estrogen receptor- $\hat{I}^{2}$ and endothelial nitric oxide synthase complex. Mol Endocrinol 25: 2003-2016.

88. Pandey M, Shukla S, Gupta S (2010) Promoter demethylation and chromatin remodeling by green tea polyphenols leads to re-expression of GSTP1 in human prostate cancer cells. Int J Cancer 126: 2520-2533.

89. Berletch JB, Liu C, Love WK, Andrews LG, Katiyar SK, et al. (2008) Epigenetic and genetic mechanisms contribute to telomerase inhibition by EGCG. J Cell Biochem 103: 509-519.

90. Mittal A, Pate MS, Wylie RC, Tollefsbol TO, Katiyar SK (2004) EGCG downregulates telomerase in human breast carcinoma MCF-7 cells, leading to suppression of cell viability and induction of apoptosis. Int J Oncol 24: 703-710.

91. Meeran SM, Patel SN, Chan TH, Tollefsbol TO (2011) A novel prodrug of epigallocatechin-3-gallate: differential epigenetic hTERT repression in human breast cancer cells. Cancer Prev Res (Phila) 4: 1243-1254.

92. Berner C, Aumüller E, Gnauck A, Nestelberger M, Just A, et al. (2010) Epigenetic control of estrogen receptor expression and tumor suppresso genes is modulated by bioactive food compounds. Ann Nutr Metab 57: 183189

93. Thakur VS, Gupta K, Gupta S (2012) Green tea polyphenols causes cell cycle arrest and apoptosis in prostate cancer cells by suppressing class I histone deacetylases. Carcinogenesis 33: 377-384.

94. Vanden Berghe W (2012) Epigenetic impact of dietary polyphenols in cancer chemoprevention: lifelong remodeling of our epigenomes. Pharmacol Res 65 565-576.

95. Sporn MB, Dunlop NM, Newton DL, Smith JM (1976) Prevention of chemica carcinogenesis by vitamin A and its synthetic analogs (retinoids). Fed Proc 35 1332-1338.

96. Lu Y, Yao R, Yan Y, Wang Y, Hara Y, et al. (2006) A gene expression signature that can predict green tea exposure and chemopreventive efficacy of lung cancer in mice. Cancer Res 66: 1956-1963.

97. Sakata M, Ikeda T, Imoto S, Jinno H, Kitagawa $Y$ (2011) Prevention of mammary carcinogenesis in $\mathrm{C} 3 \mathrm{H} / \mathrm{OuJ}$ mice by green tea and tamoxifen. Asian Pac J Cancer Prev 12: 567-571.

98. Adhami VM, Ahmad N, Mukhtar H (2003) Molecular targets for green tea in prostate cancer prevention. J Nutr 133: 2417S-2424S.

99. Adhami VM, Mukhtar H (2006) Polyphenols from green tea and pomegranate for prevention of prostate cancer. Free Radic Res 40: 1095-1104.

100. Adhami VM, Mukhtar H (2007) Anti-oxidants from green tea and pomegranate for chemoprevention of prostate cancer. Mol Biotechnol 37: 52-57.

101. Ju J, Lu G, Lambert JD, Yang CS (2007) Inhibition of carcinogenesis by tea constituents. Semin Cancer Biol 17: 395-402.

102. Koh YW, Choi EC, Kang SU, Hwang HS, Lee MH, et al. (2011) Green tea (-)-epigallocatechin-3-gallate inhibits HGF-induced progression in oral cavity cancer through suppression of HGF/c-Met. J Nutr Biochem 22: 1074-1083.

103. Siegel R, Naishadham D, Jemal A (2013) Cancer statistics, 2013. CA Cancer J Clin 63: 11-30.

104. Yoshizawa S, Horiuchi T, Fujiki H, Yoshida T, Okuda T, et al. (1987) Antitumor promoting activity of (-)-epigallocatechin gallate, the main constituent of Tannin in green tea. Phytother Res. 1: 44-47.

105. Fujiki H, Suganuma M, Imai K, Nakachi K (2002) Green tea: cancer preventive beverage and/or drug. Cancer Lett 188: 9-13.

106. Kurahashi N, Sasazuki S, Iwasaki M, Inoue M, Tsugane S, et al. (2008) Green tea consumption and prostate cancer risk in Japanese men: a prospective study. Am J Epidemiol 167: 71-77. 
Citation: Schramm L (2013) Going Green: The Role of the Green Tea Component EGCG in Chemoprevention. J Carcinogene Mutagene 4: 142. doi:10.4172/2157-2518.1000142

Page 6 of 6

107. Bettuzzi S, Brausi M, Rizzi F, Castagnetti G, Peracchia G, et al. (2006) Chemoprevention of human prostate cancer by oral administration of green tea catechins in volunteers with high-grade prostate intraepithelial neoplasia: a preliminary report from a one-year proof-of-principle study. Cancer Res 66 : 1234-1240.

108. Brausi M, Rizzi F, Bettuzzi S (2008) Chemoprevention of human prostate cancer by green tea catechins: two years later. A follow-up update. Eur Urol 54: 472-473.

109. Tsao AS, Liu D, Martin J, Tang XM, Lee JJ, et al. (2009) Phase II randomized, placebo-controlled trial of green tea extract in patients with high-risk oral premalignant lesions. Cancer Prev Res (Phila) 2: 931-941.

110. Shimizu M, Fukutomi Y, Ninomiya M, Nagura K, Kato T, et al. (2008) Green tea extracts for the prevention of metachronous colorectal adenomas: a pilot study. Cancer Epidemiol Biomarkers Prev 17: 3020-3025.

111. Inoue M, Tajima K, Mizutani M, Iwata H, Iwase T, et al. (2001) Regular consumption of green tea and the risk of breast cancer recurrence: followup study from the Hospital-based Epidemiologic Research Program at Aichi Cancer Center (HERPACC), Japan. Cancer Lett 167: 175-182.

112. Suzuki Y, Tsubono Y, Nakaya N, Suzuki Y, Koizumi Y, et al. (2004) Green tea and the risk of breast cancer: pooled analysis of two prospective studies in Japan. Br J Cancer 90: 1361-1363.

113. Wu AH, Yu MC, Tseng CC, Hankin J, Pike MC (2003) Green tea and risk of breast cancer in Asian Americans. Int J Cancer 106: 574-579.

114. Yang G, Shu XO, Li H, Chow WH, Ji BT, et al. (2007) Prospective cohort study of green tea consumption and colorectal cancer risk in women. Cancer Epidemiol Biomarkers Prev 16: 1219-1223.

115. Yang G, Zheng W, Xiang YB, Gao J, Li HL, et al. (2011) Green tea consumption and colorectal cancer risk: a report from the Shanghai Men's Health Study. Carcinogenesis 32: 1684-1688.

116. Yuan JM (2011) Green tea and prevention of esophageal and lung cancers. Mol Nutr Food Res 55: 886-904.

117. Arts IC (2008) A review of the epidemiological evidence on tea, flavonoids and lung cancer. J Nutr 138: 1561S-1566S.

118. Yuan JM, Sun C, Butler LM (2011) Tea and cancer prevention: epidemiological studies. Pharmacol Res 64: 123-135.

119. Potenza MA, Marasciulo FL, Tarquinio M, Tiravanti E, Colantuono G, et al (2007) EGCG, a green tea polyphenol, improves endothelial function and insulin sensitivity, reduces blood pressure, and protects against myocardial I/R injury in SHR. Am J Physiol Endocrinol Metab 292: E1378-1387.

120.Wolfram S (2007) Effects of green tea and EGCG on cardiovascular and metabolic health. J Am Coll Nutr 26: 373S-388S.

121. Hsieh TC, Wu JM (2008) Suppression of cell proliferation and gene expression by combinatorial synergy of EGCG, resveratrol and gamma-tocotrienol in estrogen receptor-positive MCF-7 breast cancer cells. Int J Oncol 33: 851-859.

122. Wu D, Guo Z, Ren Z, Guo W, Meydani SN (2009) Green tea EGCG suppresses $T$ cell proliferation through impairment of IL-2/IL-2 receptor signaling. Free Radic Biol Med 47: 636-643. 